\title{
Review Article \\ The Crises of Civilization: Exploring Global and Planetary Histories (2018) by Dipesh Chakrabarty
}

\author{
Publisher: Oxford University Press (2018) \\ Language: English \\ ISBN-13 (print edition): 978-0-19-948673-1 \\ ISBN-10 (print edition): 0-19-948673-5
}

\section{Reviewed by}

Shikha Vats

Doctoral Fellow and Teaching Assistant, Department of Humanities E Social Sciences, Indian Institute of Technology - Delhi. Email: shikhavats.iitd@gmail.com

W. E. B. Du Bois (1903) had famously said that the problem of the twentieth century "is the problem of the color-line" (p. 13). Dipesh Chakrabarty declares, in this new volume, that the question of the twenty-first century will be that of climate crisis. The major events of the twentieth century, including the processes of imperialism, colonization, and globalization led to widespread migration of people all across the globe framing new intersubjective equations such as oppressor-oppressed, privileged-marginalized, mostly along what Du Bois called 'the color-line'. The major fallout of this colonial and capitalist project in the last century has been global warming which is set to affect the entire planet and hence needs to be at the forefront of all policy decisions in the twenty-first century. In order to grapple with this new age of the Anthropocene ${ }^{i}$, whereby human beings have become a geophysical force capable of altering the course of the planet, Chakrabarty urges a rethinking and reformulation of the discipline of history.

The Crises of Civilization brings together a host of essays on postcolonial, global and planetary concerns. Most of these essays have been independently published before in various journals. However, they have been edited further to form a part of an evolving engagement with some key issues, which have consistently occupied Chakrabarty's oeuvre. The volume follows a bipartite structure, with the first section titled 'Global Worlds' and the second section 'The Planetary Human'. The first section highlights the heterogeneity of the 'global' worlds wherein the encounter between the west and the east happens in a big way, at first, during colonial rule, and later, in the form of almost a 'reverse migration' due to globalization. Chakrabarty, in this section, discusses the limitations of the Eurocentric thought ${ }^{\mathrm{ii}}$, emergence of capitalism in the non-western societies within a different vocabulary from that of western modernity, and finally, the relationship between the anti-colonial and postcolonial thought through theory, friendship and literature. It ends with the chapter on the uses of utopian thought which acts as a bridge between the current and the next section, which is preoccupied with imagining a viable future in the event of climate crisis. The next section, then, includes Chakrabarty's thought provoking series of essays

(c) AesthetixMS 2020. This Open Access article is published under a Creative Commons Attribution Non-Commercial 4.o International License (http://creativecommons.org/licenses/by-nc/4.o/), which permits non-commercial re-use, distribution, and reproduction in any medium, provided the original work is properly cited. For citation use the DOI. For commercial re-use, please contact editor@rupkatha.com. 
on the issues of global warming, climate justice, and the urgent need to rethink various theoretical concepts and the attendant disciplines as not just concerned with the human but also the non-human, the environment, and the flora-fauna. Divided into these two sections, the book is however, united by its author's continued contemplation over the discipline of history and how it has evolved through the late 2oth and early 21st century, and where it is headed. The book is a composite volume which seeks to highlight the concerns of our present times through the lens of history keeping a mindful eye on the future of our civilization.

The book begins with a semi-autobiographical 'Introduction' which traces Chakrabarty's scholarly course from his early days in Calcutta to his doctoral studies and work in Australia, and finally the journey to the United States. This account narrates Chakrabarty's journey across various countries and continents, and also across various disciplines. He highlights the importance of being in these places at various points of time in his life to remind the reader, the value of lived experiences. Some of these encounters were thought provoking in their inherent contradictions, others formed a learning curve and yet others were instrumental in bringing Chakrabarty in close contact with several academics who helped shape the course of his own research. For instance, during his formative years at IIM Calcutta, Chakrabarty became aware of the fundamental conflict in the institute's vision as a premier management institute, established in mid 1950s, in the shadow of the newly independent nation-state. Chakrabarty (2018) notes that "it was as if the Indian manager was meant to look forward to a capitalist future but carry a deep anti-colonial, anti-capitalist memory" (p. xxii). Here, the newly set-up institute appears as a microcosm of the newly independent nation: both meant to tread the path of modernity while being circumspect of mimicking the colonial mores.

Australia, Chakrabarty's next stop, taught about the "problems of orality, memory, and deep human pasts that could be rendered academic through the disciplines of pre-history and archaeology" (p. xxix) vis-a vis aboriginal history. Finally, it is his arrival in the US that brings a sense of affinity with like-minded intellectuals (some of whom were members of the subaltern studies group) and established him as a leading historian of our times. Through this introductory piece, Chakrabarty revisits all the various places, cultures, people, and their respective histories which shaped his thought and were in turn shaped by his work. The 'Introduction' reads almost like an account of his rites of passage; as though before Chakrabarty can begin charting the history of civilization, he must first recollect his own history as a historian.

The first chapter deals with the question of the arrival of modernity in South Asia: whether it arrived late or early, in its identifiable, belated or alternative form. Chakrabarty discusses the peasant as a revolutionary subject somewhat different from the Western individualistic bourgeoisie. Here, the peasant, in being unaccustomed to the practices of modernity is still capable of community-based social setup. This allows for what he calls as peasant's 'backwardness' to become a historical advantage, and therefore, belatedness of modernity's arrival in the South Asian subcontinent becomes a possibility for creating forms of alternative modernity (Chakrabarty, 2018). Further, Chakrabarty analyses a host of terms as 'substitutions', 'stand-ins' replacements, displacements, and disguises of what has been called "the original revolutionary subject of Europe" (p. 10). He evokes the figure of the 'peasant', the 'proletariat', the 'governed', 'the wretched of the Earth', and the 'multitude iii , to indicate expansiveness and polysemy of language which allows the postcolonial societies to articulate their own encounter with the capitalist modernity. The next chapter continues with a meditation on the postcolonial political economy. Chakrabarty discusses the claims that are often levelled against postcolonialism: that of being too theoretical, textual, and of privileging political over the 
economic factors. In a pedagogic move, the author underlines the importance of reading any discipline, be it economics or political science, with respect to their historical origins.

Following up on his own dictum, Chakrabarty peers into the historical beginnings and development of the postcolonial thought in the next two chapters. Chapter 3 titled 'An AntiColonial History of Postcolonial Thought' provides lucid distinction between the ideology of anticolonialism and postcolonialism and the shift from pedagogical politics of the former to the dialogical politics of the latter. While the anti-colonial fervour saw leaders assuming the position of a teacher/mentor, who taught how to be a 'citizen' to the unassuming masses, the postcolonial disillusionment, on the other hand, required a form of dialogical politics which would be more receptive to the grievances and demands of this very citizenry. At the same time, the question of English language gaining dominance in the aftermath of colonial rule also became a pertinent issue for the postcolonial thinkers. Here, Chakrabarty manages to succinctly tie up the various threads associated with language hierarchies, creative writing, political thinking, and the politics of difference within the broad postcolonial umbrella. Setting aside both the models of wholesale acceptance of English $^{\text {iv }}$ and the rigid rejection of this foreign English tongue ${ }^{\mathrm{v}}$, Chakrabarty highlights the strong need to tread a middle path, which requires one to embrace the other, while maintaining one's own difference. This was evident in both the anti-colonial thinkers as well as later day postcolonial writers: "the way forward was a world of multilingual individuals who would appreciate language both as means of communication and as repositories of difference" (p. 51, 52). The anti-colonial preoccupation with the idea of freedom and the postcolonial mold of forging new solidarities both boiled down to the same idea: "to be able to celebrate difference without either closing [oneself] off to others or losing [oneself] in some universal sameness, was a condition of freedom" (p. 52). The fourth chapter discusses the concept of 'civilization' which actually worked as the plug that opened up space for dialogue, interaction, and negotiation between the colonizers and colonized. However, after independence, the idea of 'civilization' morphed into the idea of progress in a globalized world economy.

The next two chapters in the book discuss the literary friendships and legacies formed by writers, poets and historians in colonial Bengal. Tagore's friendship with Moody ${ }^{\text {vi }}$ was also enabled by the ethos of the civilization, which helped literary exchanges thrive despite the eastwest divide. The seventh chapter explains how literature in colonial Bengal became the dominant mode of expression for expressing the national spirit and consequently, the ethnic Bengali identity. Thus romantic nationalism became a crucial trope in literary writings to convey the spirit of resistance against the colonizers. This chapter forms an important part of interdisciplinary writing where Chakrabarty analyses archival Bengali literature and history of 19th century to trace the porous formal restrictions of both the disciplines.

Seventh and the final chapter in this section titled 'Reading Fanon: What Use is Utopian Thought', brings the two prominent issues of this volume, that is, globalization and global warming, in close conversation with each other. Chakrabarty explores the basic rift between the two: while literature on globalization focusses on the cultural and historical differences between human beings, the literature on global warming, on the other hand, views humans as constitutive of one species who have collectively wrought unprecedented damage on the planet. To quote Chakrabarty, "the event of climate crisis presents a moment of collective and shared, yet differentiated responsibility" (p. 143), because the question of climate justice ${ }^{\mathrm{vii}}$ pertaining to unequal distribution of resources (fossil fuels etc.) is unmissable. This line of thought also looks to the future for better alternatives and in this bid, attempts to connect the utopianism of the viewpoint with the humanism needed in such circumstances. Here, Chakrabarty turns to Fanon 
whose negotiation between the négritude movement ${ }^{\mathrm{vii}}$ and assimilation with white identity, provides a space which brings together the utopian and the practical. The essential nature of utopian thought in the context of climate crisis is best summed up by Chakrabarty in the following words, "to keep alive utopian thought is to keep alive the possibility of a politics that can supplement- not displace- the politics of the possible" (p. 158). This chapter, then, functions as a portal or a go-between for the conversation to move from the 'global worlds' to the 'planetary human' or from globalization to global warming.

The second section of the book involves all the debates involved in studying climate change in its relationship, primarily with history, but also with literature, postcolonial studies and politics. Chapter 8 titled 'The Climate of History: Four Theses' introduces Chakrabarty's basic definitions (aligned with those of other thinkers) of various keywords like the 'globe', 'world', 'Earth', and 'planet', and how each invocation may differ, even if slightly, in its connotations, from the other. Further, this chapter grounds Chakrabarty's widely accepted proposition: in the event of climate crisis, there is a rift between natural history and human history, and consequently, a need to reinvent the discipline of history for our times (p. 166). The other chapters, including a couple of interviews, make up for a comprehensive view on the climate change debate and the crucial need of every discipline to address it urgently. There is a certain shift from the politics of difference which characterized Chakrabarty's earlier scholarship on postcolonial thought towards a politics of universal, or as is called 'the planetary 'human as a whole, responsible for the unprecedented global warming. Some thinkers, primarily the Left leaning political analysts ${ }^{\mathrm{ix}}$ have criticized this move as problematic. However, it seems, with this volume, that Chakrabarty has managed to think through this seeming divide between the postcolonial camp and the climate change debaters, and not in the least, uncritically.

Chakrabarty's key achievement in this volume lies in its very title: 'The Crises of Civilization'. The reviewer is left thinking about the double movement entailed in the title, one which is obvious, spelling a sense of doom, and the other, which is more subtle, wherein the proposed solution to the crises is entailed in the keyword 'civilization'. To explain further, Chakrabarty's detailed discussion on civility and civilization, accompanied with traditional 'humanism', and modernism, holds the key to thinking ahead on this impasse of climate crisis. To begin with, postcolonial studies asks probing questions on the nature of western civilization, which even though was founded on the highest ideals of civility, i.e., equality, freedom, liberty, was still involved in the worst practices of oppression including slavery and colonization. Thus, western civilization is exposed for being the opposite of what it prides itself on, 'civility'. Despite this, the way ahead lies in more such probing questions: how is civilization related to humanism; is one the subset of the other or are they fundamentally oppositional, can some specifically manipulated ideas of a particular kind of civilization, say 'superior civilization' lead to the worst of anti-humanist events, like the war? The Bengali term 'sabhyata', which may be the equivalent of 'civilization', was introduced in the language with the advent of the British rule. Tagore, in his essay with the same title ${ }^{\mathrm{x}}$ begins with these questions, and Chakrabarty in this book, continues the engagement by broadening the scope from the global to the planetary dimensions, and thereby, introducing the utopianism needed for such a move. 
5 | The Crises of Civilization: Exploring Global and Planetary Histories (2018) by Dipesh Chakrabarty

\section{Endnotes}

${ }^{\mathrm{i}}$ Anthropocene refers to the proposed geological epoch when human activity becomes a propeller of bringing about changes to the whole planet.

ii Chakrabarty's (2008) Provincializing Europe, discusses this aspect of the need for an alternative vocabulary to grapple with modernity in postcolonial societies, in greater detail.

iii These phrases have been borrowed from Gramsci, Marx, Partha Chatterjee, Frantz Fanon, and Hardt and Negri respectively.

${ }^{\text {iv }}$ Refers to the ideology upheld by Nehru.

${ }^{\mathrm{v}}$ Refers to the politics espoused by Ngugi wa Thiongo.

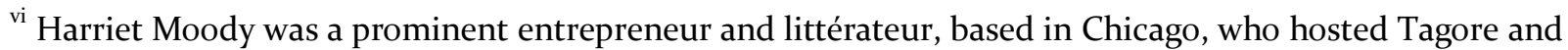
his family in Chicago and New York on their visit to the United States on several occasions.

vii 'Climate justice' refers to the idea that the burden of decreasing the fossil fuel use should fall on developed countries who have been major players in bringing the global warming to this stage, in the first place. On the other hand, the developing countries, may be allowed to gradually lessen their energy resources so that they can contribute to a meaningful change while being at par in the globalized economy. 'Climate justice' is about the ethical and political implications of global warming. See Nazrul Islam et al., (2017).

viii Popularized by thinkers like Senghor and Césaire, négritude movement involved a fierce assertion of the black identity- in its language, mannerism, cultural mores and practices.

${ }^{\text {ix }}$ See Boscov-Ellen (2018) for a trenchant critique of this shift in Chakrabarty's scholarship.

x Tagore's original essay, written in 1941, in Bengali was titiled 'Sabhyatar Shankat'.

\section{References}

Boscov-Ellen, D. (2018). Whose Universalism? Dipesh Chakrabarty and the Anthropocene. Capitalism Nature Socialism, 31(1), 70-83. doi:10.1080/10455752.2018.1514060.

Chakrabarty, D. (2008). Provincializing Europe: Postcolonial Thought and Historical Difference. Princeton, N. J.: Princeton University Press.

Chakrabarty, D. (2018). The Crises of Civilization: Exploring Global and Planetary Histories. New Delhi: Oxford University Press.

Du Bois, W. E. B. (1989). The Souls of Black Folk. New York: Penguin Classics.

Nazrul Islam, S. \& Winkel, John. (2017, October). Climate Change and Social Inequality. UN/DESA Working Paper No. 152. https://www.un.org/development/desa/publications/working-paper.

\section{Bio-note}

Shikha Vats is currently a Doctoral Fellow (Literature) and Teaching Assistant at the Department of Humanities \& Social Sciences, Indian Institute of Technology- Delhi 